\title{
Signs of Her
}

\author{
Sheila Stewart
}

\begin{abstract}
Vestiges d'une vie
Des bas-culottes, un chemisier marin, un sac à main manifestent son absence. Tout ce qui reste de la mère de la narratrice, ce sont les vêtements demeurés dans le placard après sa mort: les vestiges d'une vie, une famille en soi. La narratrice tente de déchiffrer les signes laissés par sa mère à travers ses vêtements et veut décrire les différents passages de sa vie à travers les souvenirs que ces témoins font ressurgir. Un voyage effectué en Irlande en 1991 en est un exemple. Mais que sait-elle au juste? Que disent exactement ces signes que sa mère lui a laissés?
\end{abstract}

the stockings that she put in the drawer

two grey hairs on the high ruffled collar of a navy blouse

a kleenex in the pocket of a plaid skirt

small white and pink mints in a black clutch purse

signs that she was here

sorting her outfits

into four piles: to keep, to send to Ireland,

for a friend, for the Salvation Army

trying on her Donegal tweed suit

stepping into her elegance

wrapped in what's left

I want to try on the way she said calmly

he has no power over me

the way she banged the brass gong

as her husband's and son's voices exploded around the room

the way she wrapped my nightie around a hot water bottle

left it on my pillow with a note

the way she packed me a lunch of wheaten salad sandwiches

the crusts cut off

the way she said of a trifle with fresh strawberries, raspberries, custard and cream 
it goes round my heart like velvet

finely crocheted white lace collars in the drawer don't know who made them

they were round her neck

a closet to clear

caught up with what's in the pockets

I could fill the pockets with notes

what I know

bought at Norma Bradley's Dress Shop in Waterloo

wore to Ireland in the winter of 1991

held her first grandchild on the lap on this pleated skirt

wore this sleeveless dress on a warm summer evening in 1975

at Goderich when she spread out a table-cloth

and opened a wicker picnic basket by the lake

what I know and don't know

don't know about her

how to clear a closet

a row of handbags

two round hat boxes

her clothes on the empty bed

my photo in her wallet

my photo beside a pile of hankies folded in triangles

in the top drawer

my name on a small name tag in her jewelry box

one left over after she had sewed the others

on the inside of the collars of my clothes 